\title{
LEGAL AND FINANCIAL INSTRUMENTS SUPPORTING THE INNOVATION AND TECHNOLOGY TRANSFER
}

\author{
PRÁVNE A FINANČNÉ NÁSTROJE \\ PODPORUJÚCE INOVÁCIE \\ A TRANSFER TECHNOLÓGIÍ
}

\author{
Danka MORAVČÍKOVÁ - Zuzana ILKOVÁ - Petra ŠTEFEKOVÁ *
}

\section{Introduction}

Innovations in agri-food sector are rather young policy issues that have become an important objective of national and regional development policies. Support of innovation in the field of agriculture is one of the priorities of the Smart specialisation strategy of the Slovak Republic (SK RIS3), which is directly related to the Europe 2020 strategy and the Innovation Union. SK RIS3 identifies not only priorities with above average potential, but also the area of agriculture, food and biotechnology. The European Commission stresses also the importance of measures aimed at boosting demand for innovation in the initiative of the Innovation Union. It states

\section{Abstract (EN)}

Issues of innovation and technology transfer are framed by a broad legislation and financial schemes at the European and national level. In context of the strategy Europe 2020 and the initiative Innovation Union, the mutual interconnection between the new knowledge creation and its economic valuation is important for competitiveness of the economy. Innovation systems are characterized by a large scale of different actors and dynamic interactions between them. The intensity of the innovation activity of enterprises is mostly influenced by the level of their legal awareness and by the ability to utilize the innovation mechanisms and opportunities for transfer of knowledge, modern technologies and practices. The paper characterizes selected legal and financial mechanisms and points out the possibilities and problems related to their implementation in economic sphere, particularly in the agrifood sector. At the beginning, the authors describe the key aspects of the innovation policy and technology transfer in the EU and Slovakia. Next parts of the paper are focused on the issue of legal institutes concerning the industrial property and on the financial instruments for the period 2014-2020 emphasizing the innovative ones and possibilities of their combination. In the final part, the authors point out the barriers and possibilities in innovation implementation and in the process of transfer of technologies and knowledge to economic sphere.

\section{Keywords (EN)}

innovation, technology transfer, knowledge transfer, agrifood sector that the potential of the single market should be activated through policies that stimulate demand for innovation ${ }^{(1),(2)}$. The necessity of innovation in agriculture underlines the fact that ensuring food security will be one of the most serious global challenges in the coming years. According to Food

1) European Commission (2010). Communication Europe 2020 Flagship Initiative Innovation Union COM (2010) 546 final, 6.10.2010

(2) Izsak K. - Edler, J. (2011). Trends and Challenges in DemandSide Innovation Policies in Europe. Thematic Report 2011 under Specific Contract for the Integration of INNO Policy TrendChart with ERAWATCH (2011 - 2012). Brusel: European Commission, DG Industry and Enterprise.

\section{Abstrakt (SK)}

Problematika inovácií a transferu technológií je rámcovaná rozsiahlou legislatívou a finančnými schémami na európskej i národnej úrovni. V kontexte stratégie Európa 2020 a iniciatívy Inovačná únia je pre konkurencieschopnost' ekonomiky dôležité vzájomné prepojenie tvorby nových znalostía ich ekonomického zhodnotenia. Inovačné systémy sú charakteristické množstvom rôznorodých aktérov a dynamickými interakciami medzi nimi. Intenzitu inovačnej aktivity podnikov ovplyvňuje najmä úroveň ich právneho vedomia a schopnost' využívat' inovačné mechanizmy a príležitosti pre transfer poznatkov, moderných technológií a postupov. Článok charakterizuje vybrané právne a finančné mechanizmy a poukazuje na možnosti a problémy súvisiace s ich implementáciou v hospodárskej praxi, predovšetkým v agropotravinárskom sektore. V úvode autorky popisujú klúčové aspekty inovačnej politiky a transferu technológií v EÚ i na Slovensku. Ďalšie časti príspevku sú zamerané na problematiku právnych inštitútov súvisiacich s priemyselným vlastníctvom a na finančné nástroje pre obdobie 2014-2020 s dôrazom na inovatívne finančné nástroje a možnosti ich kombinácie. V záverečnej časti autorky poukazujú na bariéry a možnosti pri implementácii inovácií a v procese transferu poznatkov i technológií do hospodárskej praxe.

\section{Klúčové slová (SK)}

inovácie, transfer technológií, transfer poznatkov, agropotravinársky sektor

\footnotetext{
* Slovak University of Agriculture in Nitra
} 
and Agriculture Organization (FAO), global food demand will rise by $60 \%$ by 2050 , further a substantial increase in the demand for feed, biomass and bio-materials is expected. In addition, there is a slowdown in agricultural productivity growth due to reductions in investment in agricultural $R \& D$ (R\&D) and increasing pressure on natural resources (water, soil) and the environment. Impact of climate change also plays an important role.

Innovation process occurs within innovation systems which consist of public and private organizations, institutions and companies that are in various ways connected and have the necessary technical, commercial and financial competencies and inputs necessary for innovation ${ }^{(3)}$. Agricultural development is determined by innovations that represent a basic source of productivity, economic growth and competitiveness, and generally play an irreplaceable role in creating jobs, poverty reduction, global food security, environmental sustainability and driving the socio-economic development. According to The Innovation Policy Platform (4) "innovation in the agricultural sector involves the development of healthier, safer and more nutritious food for human and animal consumption, new breeding techniques, and fuel for industrial use. Agricultural innovation has the potential to increase the productivity and adaptability of crops, diversify the variety of agricultural crops, enhance the nutritional value of food, feed increasing farm animal populations, and provide fuel for a growing range of industrial uses without depleting available land, water and biodiversity resources." Innovation is about solving problems and taking advantage of opportunities, and it is characterised by a combination of technical, economic, organisational and external drivers. Innovation takes place when the network involved in the production changes the way how they do things, which suggests, that innovation entails the patterns of interactions between people, tools and resources. Moreover, a learning process is also associated with innovation processes, as changes, which result in improvements in social or economic organisation, also increases the available knowledge ${ }^{(5),(6),(7)}$.

The typical innovation is based on the investment in scientific research realized at universities or research institutions and on the number of patents. It is often associated only with high-tech products and research and development (R\&D) activities mostly carried in urban areas. Most of rural settings and agricultural firms (especially SMEs) lack this possibility. Innovation in a rural space can be linked with traditional activities (agriculture, farming and/or tourism)

(3) Inter-American Institute for Cooperation on Agriculture (2014). Innovation in Agriculture: a key process for sustainable development. Institutional position paper, San Jose, May 2014

(4) https://innovationpolicyplatform.org/content/ agriculture?topic-filters $=11399$

(5) Klerkx, L. - Gildemacher, P. (2012). The Role of Innovation Brokers in Agricultural Innovation Systems. In: Agricultural Innovation Systems: An Investment Sourcebook

(6) Fortuin, F. (2007). Strategic alignment of innovation to business. Balancing exploration and exploitation in short and long life cycle industries. Wageningen: Wageningen Academic Publishers.

(7) Hamel, G. and Prahalad, C.K. (1994). Competing for the Future. Boston: Harvard Business School Press, 1994. and combined with new or improved technologies. According to the methodological framework of the survey of the European Commission on the role of public support in the commercialisation of innovations ${ }^{(8)}$ new or significantly improved services, goods, marketing strategies, organisational structures and processes are considered as the general types of innovations. The cross-national analysis on innovation processes in agriculture and rural development points out concrete innovations and innovation strategies ${ }^{(9)}$. There are several important challenges of designing the rural and agricultural innovation system for the twenty-first century that are different in comparison to the previous period (e.g. in terms of changed position of the public sector and the new structure of actors, such as private research institutions, advisory services, as well as civic organisations).

\section{Material and methods}

This paper focuses on the analysis of legal and financial mechanisms in the field of innovations and knowledge and technology transfer, particularly concerning the agrifood sector and points out the possibilities and problems related to their implementation in economic sphere. It takes into account the international, as well as, the national standards, instruments, schemes and mechanisms, using the available information at the relevant websites and in on-line publications. The authors use the method of content analysis based on the general scientific methods and interpretation.

\section{Legal Institutions Related to the Industrial Property and Their Importance for the Agri-food Sector}

The subject of civil relations in accordance with $\S 118$ of the Civil Code are things and if their nature admits, rights and other assets. The other asset values also include the intanglible assets (intangible good, ideal objects). Both, theory and practice are trying to define the concept of asset, the substance of which it is constituted from intellectual creations expressed in an objective form. Intangible assets such as intellectual creations belong to the group of rights that are referred to as intellectual property rights.

The concept of intellectual property was defined in the Article 2 of the Convention establishing the World Intellectual Property Organization, signed in Stockholm on July 14, 1967 (Decree of Ministry of Foreign Affairs no. 69/1975 Coll.) according to which intellectual property includes the rights related to: literary, artistic and scientific works; to performances of performing artists, sound recordings and radio broadcasts; to inventions in all areas of human activities; to scientific inventions, to industrial designs and models; to

(8) European Commission (2014). The role of public support in the commercialisation of innovations (Flash Eurobarometer 394).

(9) Knickel at al. (2009). Innovation processes in agriculture and rural development. 
trademarks and service marks as well as commercial names and designations; to protection against unfair competition and all other rights resulting from intellectual activity in the industrial, scientific, literary and artistic fields. Based on the above, it can be stated that intellectual property includes two groups of rights - copyrights including rights related to copyright (1), and the rights to objects of industrial property, including industrial property rights to the mark $(2)^{(10)}$.

Besides rights to copyright and industrial property rights, the system of intellectual property involves also other rights relevant to the entrepreneurial activity, such as the right to the commercial name, rights related to the logo, to the domains, to the rationalization proposals, then the rights related to new varieties of plants and breeds of animals, the rights related to new methods of diagnosis and treatment of human and animals, the rights related to new ways of plants and animals protection for which the protection is provided either by copyright acts or specific legislation.

Industrial rights are the results of technical creative activity of their producers and unlike copyrights, they need special registration for their formation. Particular objects of industrial rights and their legislation is based on the terminology of basic international treaties (Paris Convention for the Protection of Industrial Property, Strasbourg Agreement Concerning the International Patent Classification, Patent Cooperation Treaty, the European Patent Convention, the Convention on the Visegrad Patent Institute, the Agreement on Trade-Related Aspects of Intellectual Property Rights -TRIPS and other relevant international conventions that regulate specific areas of industrial property). In addition to international multilateral treaties for legal protection of industrial property in states of the EU, the binding rules are laid down in the relevant legal acts of the EU.

Industrial rights are summary of special exclusive rights linked to the individual objects of industrial right: inventions, utility models, industrial designs, topographies of semiconductor products, trademarks and designations of origin. Legislation regulating individual objects reflecting the basic principles of the Paris Convention:

- the principle of territoriality, granting the legal protection in the state in which the applicant asks for protection,

- the principle of priority, the priority right arising from the date of obtaining an application about the object of industrial property in the national patent office. Based on the submitted application in one contracting state, the applicant shall enjoy the right of union priority in all contractor states on the identical object,

- the principle of national regime - the citizens of each contracting state of the Union shall enjoy the same benefits in other states of the Union as those provided to them in their own state.

Due to the wide range of industrial right objects in terms of the defined objective, the paper is focused on selected industrial property law institutes, namely inventions, utility mod-

\footnotetext{
(10) More detailed division of Intellectual Property Rights: VOJČíK, P. et al. Intellectual property right, p.33-34.
}

els and legal protection of new plant varieties.

The legal regulation of inventions as subjects of industrial property is laid down in the patent law (Act No. 435/2001 Coll. on patents, supplementary protection certificates and on amendments to some acts). The act governs legal relationships arising in relation to the creation, legal protection and application of the invention. For inventions that meet the conditions of patentability, the Industrial Property Office of the SR will grant a protecting document - patent. The Industrial Property Office is the place where citizens and other persons residing or having the business establishment on the territory of the Slovak Republic may file international or European patent applications under the relevant international treaties.

Following objects may be considered as an invention: a new product or a new manufacturing process that meets the conditions of patentability, namely: novelty, the result of inventive activity, industrial applicability. Novelty is based on the fact that the technical solution is not part of the state of the art and it is a worldwide novelty that operates absolutely and objectively. The Industrial Property Office is determining novelty during the patent application process.

The subject matter of the application must be the result of inventive activity, and therefore, the Industrial Property Office during the application procedure examines whether the new invention does not result objectively from the state of the art. The invention is considered to be industrially usable if its subject is to be manufactured or can be used in any sector, in particular in the industry and agriculture. This means that the invention can be repeatedly used during economic activity and with the same technical result.

Patents are also granted for biotechnological inventions related to a product consisting of biological material or containing biological material, or the way in which the biological material is being produced, processed or utilized.

The subject matter of the invention may no longer be excluded from patentability ( $\S 5$ par. 3 and $\S 6$ of the Act). Granting of the patent is the result of a preliminary research, after which the application is published with the right of priority, and the result of a complete survey by the Industrial Property Office that is realized no later than 36 months after submission of application by authorized person.

Effects of a patent, which is valid for a maximum of 20 years from the date of submitting the application, occur from the day of notification of the patent in the Industrial Property Office Bulletin. The patent owner acquires exclusive rights to use the invention, to grant the consent to other persons to use it under the terms of the license agreement, or transfer the patent to other persons.

Utility patterns, as well as, inventions, are subject matters of an industrial and technical nature and can be the subject of business relationships. Legal relations arising in relation to the creation, legal protection and application of the technical solution, which is a utility model in our territory, are regulated by the Act no. 517/2007 Coll. It is necessary to agree with the opinion ${ }^{(11)}$ that the reason for introducing this

(11) TELC, I. - TŮMA, P. Overview of Intellectual Property Rights. Czech Legal Protection 2 p. 55-56. 
legal protection is the fact that the patent system can not be applied to subjects of daily use ready for production, to subjects with a lower inventive level, complexity and length of the patent procedure.

In the act, the legal protection conditions are defined analogously to the inventions: a technical solution is capable for protection by utility model; if new, it is the result of inventive activity and it is industrially usable. Compared to the invention-related amendment, the act regulates the exclusion from protection more broadly. It is not possible to protect these methods of production with the help of the utility model: methods of production of chemical and pharmaceutical substances, or the medical use of substances and mixtures. The procedure of application for a new utility model is simpler, faster and more cost-effective. It has the nature of the registration procedure, where the formal conditions of registration are examined. The period of protection of a registered utility model is four years from the date of submitting the application, and it is possible to extend its validity twice by three years upon the request of the owner of the utility model. The utility model owner has the exclusive right to use a technical solution protected by a utility model, to consent to the use of other persons or to transfer the utility model to others, and in some cases to set up a right of lien to a utility model.

In the field of industrial property, plant breeding is a very important innovation process. Plant breeding, as a targeted activity with the use of scientific knowledge and methods, is protected by copyright act. Special acts regulate the protection of results of breeding activity - new plant varieties. The legislation is established by several regulations: Council Regulation (EC) 2100/1994 of 27 July 1994 on the Community Plant Variety Rights, Act No. 202/2009 Coll. On the Legal Protection of Plant Varieties, Act No. 597/2006 Coll. on the Competence of the State Administration in the Field of Registration of Varieties of Cultivated Plants and on the Introduction of Plant Propagating Material on the Market, Government Regulation no. 50/2007 Coll. on Registrations of Growing Varieties, Government Regulation no. 51-58/2007 Coll. on Requirements for the Market Authorization of Seeds of Individual Plants. Besides the legal protection of plant varieties, Act no. 202/2009 Coll. also regulates the conditions for grating the breeder's certificate for plant varieties, the rights and obligations of persons in the field of legal protection of plant varieties, the competence of the central government authorities and the imposition of sanctions for breaching such obligations. If the plant variety fulfills the legal conditions (difference, balance, stability, novelty, marking in an appropriate way), the Ministry of Agriculture and Rural Development of the SR will grant the breeder a breeder's certificate confirming the exclusive rights of its owner. Without his/her consent, no one may use the new variety commercially. The effect of the plant variety rights is extended to the end of the twenty-fifth calendar year (Article 19, paragraph 1 and 3 of Council Regulation (EC) No. 2100/1994), and for a new vine and tree variety by the end of the thirtieth year after the year of the granting of rights.

Discussions on this issue are being held all over the world, and Europe is making efforts to include breeding of new plant varieties by classical methods under patent protection. Patent protection of nowadays freely available breeding procedures and of new plant varieties achieved by traditional breeding techniques would lead to the monopolization of the breeders' work.

In authors' opinion, the availability of knowledge, access to biological material is necessary to develop new, more quality, safer, climate change resistant plant varieties. The current legislation that excludes the granting of patents for plant varieties, breeds of animals and the biological methods of their cultivation and breeding, meets the requirements of practice and is a prerequisite for innovation in the field of achieving new plant varieties by traditional breeding techniques.

During the development of the knowledge-based economy, the importance of the application and the transfer of results of intellectual creative activity is undeniable in the agri-food sector, as well as, in all economic sectors. For business entities, it allows better and faster implementation on the market with new and innovative products, technological processes, in which inventions are embodied, utility models, or bring new varieties of plants to market. Law on Protection of Industrial Property fulfils two roles. For the owners of a patent for inventions, holder of the certificate for utility models, owners of breeding certificates through negotiated license agreements it provides returning of the funds, as well as, other compensation in case of successful transfer market. The information disclosed in the approval process logged the results of technical creative activity is for informed market participants an important source of new knowledge and its exploitation, application, production in practice can gain a competitive advantage.

\section{Science and Research as a Source of Innovation and Precondition for a Successful Transfer of Knowledge and Technology}

The results of science, research and innovations significantly affect the economic growth and development of a country. The Austrian economist Joseph Schumpeter considered entrepreneurs who are open to the implementation of innovation as key drivers of economic growth and development. He also assigned important role to business cooperation that significantly improves innovation processes. Later, the Dutch professor of sociology Louis André Leydesdorff and American professor of innovation and entrepreneurship Henry Etzkowitz introduced the theory of triple spiral model of innovation that is based on the observation of government, industry and universities within realization of innovative processes. Theory of systematic submission of proposals for achieving the effective implementation of innovations belongs to the important theories as well. Theory emphasizes mainly small businesses in the innovation processes, which 
are able to specialize already at an early stage. Small businesses develop technical innovation and by their flexibility, they may become an important partner for large businesses when implementing innovation.

The end of $19^{\text {th }}$ century is considered as essential for higher education institutions, particularly in Germany, United State, Great Britain, Canada that were regarded as research centres ensuring transfer of knowledge and innovation. Higher education institutions are often referred to as the "economy or knowledge factory". Universities have indispensable role in development and transfer of knowledge, development of innovation and economic growth. However, in order to fulfil this crucial role, it is essential for the universities to meet the requirements of suitable environment. Suitable environment for transfer of knowledge and innovation is created by political environment, suitable organization structure supporting science and research, and sources for transfer of knowledge and innovation. Political environment in the field of transfer of knowledge and innovation requires certain rules for complying responsibility among the various subjects of scientific-research centres, including particularly the application of intellectual property rights, policy of research grants and contracts, providing of consultative work and compliance with ethical standards in science and research. The fundamental objective of universities is also cooperation with various industries through which the universities ensure transfer of knowledge and innovation into practice. Universities are considered as an incubator of intellectual, economic, social and cultural development and belong to the main supporters of the regional development. They provide research results in a form of public goods - publications and in a form of private property - in joint research activities with businesses, through their graduates who bring their knowledge into practice; commercialisation and transfer of research results. Commercialisation focuses on selecting the right ideas and results of $R \& D$ and the consequently, their implementation into business environment ${ }^{(12)}$.

R\&D is regulated by the Act. No. 172/2005 Coll. on Organization of State Support for R\&D and on amending of the Act No. 575/2001 Coll. on the Organization of the Activities of the Government and on the Organization of the Central Government Authorities as amended. The subject of the Act is legislation on the conditions for state funds for R\&D. Further; it regulates the status and role of bodies active in the field of science, R\&D. It also adjusts science and technology policy at the state level, the national program for the development of science and technology, as well as, information security in science and development. Act No. 172/2005 Coll. defines research as systematic and creative activity that takes place in the field of science and technology in order to develop knowledge and the needs of society. It divides the research into basic and applied. Basic research means a systematic and creative activity aimed at acquiring new knowledge. Applied research is characterized as a systematic and creative activity, which focuses on the acquisition of new knowledge for the purpose of its use in practice.

(12) Čorej, J. et al. Univerzity, priemysel a partnerstvo. Žilinská univerzita v Žiline: EDIS 2006, ISBN 80-8070-526-7.
Development is defined as a systematic and creative activity in science and research that is using knowledge and principles of research and practice in the implementation of new or improved materials, concepts, products, services, systems, methods and processes.

Sector structure of $R \& D$ constitutes of legal entities and natural persons - entrepreneurs, who conduct R\&D. They involve state sector, including Slovak Academy of Sciences and legal persons established by the state authorities for carrying out R\&D; higher education sector and legal entities established by universities for conducting R\&D; nonprofit sector which undertakes R\&D; and lastly, the business sphere conducting $R \& D$ within its activities. According to the Act No. 172/2005 Coll., legal entities include also Center of excellence in research, that carries out the research especially in the field of science and technology, and participates in the projects and programs in the area of $R \& D$ in the international centers of $R \& D$, and which results are used in further education. Additional organizations active in the field of science and technology also include specialized organizations of science and technology, which are science and technology parks, R\&D centers and technology incubators.

Science and technology services are carried out by legal or natural persons in the field of $R \& D$, whose activities focus on the provision and dissemination of science and technology information and knowledge; on activities that support the transfer of $R \& D$ into practice; on business consulting, expertise in the R\&D; monitoring, research, data collection and analysis of the information and knowledge; technical normalization and products conformity assessment; patent and licensing activities; forensic activities, translation and interpreting within the area of R\&D; further education and lifelong education for R\&D; activities supporting the improvement of infrastructure of $R \& D$; activities supporting international science and technical cooperation.

The main bodies responsible within the area of the organization of state funds for R\&D according to Act No. 172/2005 Coll. are the Government of the Slovak Republic, Ministry of Education, Science, Research and Sport of the Slovak Republic and the central government authorities in the field of science and research. The main activities of the Slovak Republic in the field of R\&D include approval and evaluation of the long-term plan for science and technology policy at the state level; creation of conditions for its implementation; approval and evaluation of the national program of science and technology development; approval of international treaties on international cooperation in science and technology area and $R \& D$ area.

Ministry of Education, Science, Research and Sport of the Slovak Republic, in particular: creates favorable conditions and mechanisms for the development of science and technology, R\&D; coordinates the activities of central government authorities in the field of R\&D, Slovak Academy of Sciences and universities; develops proposals to support research and the development and use of its results in practice. Central government authorities in the field of $R \& D$ are involved in formulating long-term intentions and objectives of science and technology policy at the state level and their fulfillment. Slovak R\&D Agency is a budgetary organization established 
to support $R \& D$ through the provision of funds for project solutions in the field of R\&D. Also, another programs such as National program of science and technology development, state programs of $R \& D$, and infrastructural development of $R \& D$, contribute to the support of R\&D. Within the National Program of Science and Technology Development, the state budget is distributed for the Slovak R\&D Agency, for state programs $R \& D$, for state programs of $R \& D$ infrastructure development, for the incentives for $R \& D$, for securing the tasks of the Ministry of Education in the field of science and technology, and for other activities in the field of science and technology financed from the state budget.

The Bayh Dole Act from 1980, adopted in the United States was an important milestone in science, R\&D. It regulated government grants in the higher education sector by their gradual decreasing. However, this Act was beneficial for the national innovation system of the United States. Reduction of state funding for the higher education sector influenced improvement and enhanced cooperation among academia and the business sector ${ }^{(13)}$. This Act adjusted patent strategy for agencies supporting R\&D by allowing to retain property rights for inventions created during the provision of state funding. By adoption of this act, interest of universities in the transfer of R\&D results into practice had increased. However, the importance of universities in the national innovation program varied by country, especially by the economy, level of industry, and R\&D structure. Based on statistical findings, a similar law was adopted also in Germany, Belgium, and Denmark that also increased the rate of patenting ${ }^{(14)}$.

Increased rate of patenting was as well caused by technology transfer centers established by many universities and regional high-tech clusters ${ }^{(15)}$ that formed the base of important innovative companies such as Google, Apple, and Hewlett Packard. Transfer centers are usually part of universities or their subsidiaries - each form has its advantages and disadvantages. In particular, a separate transfer centers are more likely to success in cooperation with the business sector and in the process of commercialization ${ }^{(16)}$.

The World Intellectual Property Organization provides list of entities interested in the process of commercialization of $R \& D$ results. Such group of entities is formed by the universities and their scientific-research organizations, researchers, assistants, interns, employees of scientific and research institutions, students, sponsoring bodies, agencies in the field of intellectual property rights, the general public and central

(13) ETZKOWITZ, H. - WEBSTER, A. - GEBHARDT, C. - TERRA, B. R. C. (2000). The Future of the University and the University of the Future: Evolution of Ivory Tower to Entrepreneurial Paradigm. Research Policy, vol. 29, no. 2, pp. 313 - 330.

(14) LEYERSDORFF, L. - MEYER, M. (2009). The Decline of University Patenting and the End of the Bayh-Dole Effect. Scientometrics, vol. 83, no. 2, pp. 355-362.

(15) High-tech cluster, or business cluster, is geographic concentration of mutually conncected businesses, suppliers, and associated institutions in particular field. Clusters are considered to bean appropriate tool how to increase businesses productivity and competitivness at both, national and global level.

(16) GEUNA, A. - MUSCIO, A. (2009). The Governance of University Knowledge Transfer: A Critical Review of the Literature. Journal of Technology Transfer, vol. 47, no. 1, pp. 93 - 114. government authorities. These entities represent an asset in the process of commercialization at various stages, but it is possible that conflict may occur between the various entities. To resolve potential conflicts in the area of R\&D results, and for the protection of intellectual property rights, it is essential to develop internal legislation for this area that will be based on the current legislation in the intellectual property rights area. The negative aspects of transfer centers at universities include a long and difficult process of their establishment, as well as, huge difficulty of initial funding. On the other hand, positive aspects of transfer centers include mainly the results of their activities and the provision of further education and professional counseling. Transfer centers for employees of the university and scientific-research institution usually provide following services:

- market research to determine demand,

- survey of demand in databases of technological requirements,

- estimation of the commercial potential of the technology,

- search for partners in industry, the private sector and their identification,

- ensuring the inclusion of proprietary technology in the database,

- consulting,

- monitoring of financial resources for the implementation process, further development of proprietary,

- legal advice on the formation of contracts,

- consultancy in establishing of spin-off companies.

Transfer centers for the business sector provide following services in particular:

- patents databases for the sale of licenses,

- information on equipment of R\&D organizations and their use,

- consultancy,

- presentation of the results of R\&D activities,

- social events for the community of industry partners, external consultants ${ }^{(17)}$

$R \& D$ comprise creative work that is carried out on a systematic basis in order to increase knowledge and skills for their use in practice. Data necessary for innovation surveys are gathered in the field of R\&D. Innovation surveys are the basis for determining the appropriate and effective innovation strategy. The aim of $R \& D$ in innovation is to achieve improved product or service.

In addition to R\&D, businesses can obtain also technology, know-how in many forms and from various sources in regards to the development and implementation of innovations. This includes acquisition of foreign subsidies of multinational companies. Acquisition of external knowledge and technology may be realized in accordance with the relevant provisions of law related to intellectual property rights and industrial property rights, for example patents, inventions, trademarks, licenses, utility models.

(17) BALOG, M. et al. (2013). Inovatívne Slovensko - východiská a výzvy. Slovenská inovačná a energetická agentúra, Bratislava, 2013 
V. Innovative Financial

\section{Instruments and}

Possibilities of Their Use in the Process of Transfer of Knowledge and Technology

This section specifies financial instruments in the European programs and schemes for the period 2014-2020 and instruments of international organizations. It is mainly focused on European programs and funds, by which the European Union supports and implements its development policies for the period 2014-2020, and which are relevant for the development of agro sector. Additionally, there is also list of options in various international programs.

For the purpose of this paper, it is possible to divide European programs and funds, by which the European Union supports and implements its development policies for the period 2014-2020, into the following groups:
- The European Structural Funds and Investment Funds (ESIF) represent approximately $76 \%$ of the total EU budget. There are 11 common objectives set out as the priorities on the EU-level and each fund is targeted at one or at more of these priorities. ESIF funds are primarily realized through national or regional programs managed by the Member States or regions that establish the managing body for each program. ESIF are divided into the following funds: the European Agricultural Fund for Rural Development (EAFRD), European Regional Development Fund (ERDF), European Social Fund (ESF), the Cohesion Fund (CF), the European Maritime and Fisheries Fund (EMFF).

- Community funds, as opposed to ESIF, are centralized at the level of the European Commission and/or its executive agencies. The most important programs and tools that are relevant for the development of research and innovation include: EU Framework Program for Research and Innovation (Horizon 2020), Program of R\&D carried out jointly by several Member States aimed at supporting SMEs performing R\&D (Eurostars), EU Framework program for SMEs (COSME), EU Program for the

Table 1: Community funds and initiatives

\begin{tabular}{|c|c|c|c|}
\hline PROGRAM & $\begin{array}{l}\text { TYPE OF } \\
\text { SUPPORT }\end{array}$ & $\begin{array}{l}\text { POSSIBILITIES } \\
\text { OF PARTICIPATION }\end{array}$ & $\begin{array}{c}\text { AREA } \\
\text { OF SUPPORT }\end{array}$ \\
\hline \multirow{4}{*}{ HORIZON 2020} & Grants & IA, RIA, CSA: Partner in consortium & $\begin{array}{l}\text { According to the topics defined in the } \\
\text { relevant multi-annual work programs }\end{array}$ \\
\hline & Grants & $\begin{array}{l}\text { FTI: Partner in consortium (after meeting mini- } \\
\text { mum requirements) }\end{array}$ & No thematic restriction \\
\hline & Grants & $\begin{array}{l}\text { SME Instrument: possibility to participate only } \\
\text { as a subcontractor of solution or studies for the } \\
\text { companies }\end{array}$ & No thematic restriction \\
\hline & Grants & $\begin{array}{l}\text { MSCA: Hosting and sending interns (young and } \\
\text { experienced researchers) }\end{array}$ & No thematic restriction \\
\hline EUROSTARS & Grants & $\begin{array}{l}\text { Partner in consortium (after meeting minimum } \\
\text { requirements) }\end{array}$ & No thematic restriction \\
\hline \multirow{2}{*}{ COSME } & Services & $\begin{array}{l}\text { Enterprise Europe Network, IPR Helpdesk, Por- } \\
\text { tal Your Europe, Portal for internationalization }\end{array}$ & No thematic restriction \\
\hline & Grants & $\begin{array}{l}\text { Partner in consortium in the field of business } \\
\text { support (after meeting minimum requirements) }\end{array}$ & No thematic restriction \\
\hline LIFE & Grants & Partner in consortium & Environment and climate protection \\
\hline ERASMUS+ & Grants & Partner in consortium & Education and training \\
\hline ETC Central Europe & Grants & Partner in consortium & $\begin{array}{l}\text { Innovation, low-carbon economy, pro- } \\
\text { tection of natural and cultural resources, } \\
\text { transportation }\end{array}$ \\
\hline $\begin{array}{l}\text { ETC Danube Trans- } \\
\text { national Program }\end{array}$ & Grants & Partner in consortium & $\begin{array}{l}\text { Innovations, environment, culture, trans- } \\
\text { port links, energy efficiency, efficient } \\
\text { public administration }\end{array}$ \\
\hline Interreg Europe & Grants & Partner in consortium & $\begin{array}{l}\text { Research, development and innovations, } \\
\text { competitiveness of SMEs, low-carbon } \\
\text { economy, environment and resource } \\
\text { efficiency }\end{array}$ \\
\hline
\end{tabular}

Source: Innovative financial instruments and financing the research, development and innovations for practice. The report was prepared within the project Creation of the AgroBioTech Research Centre, Activity 1.7: AgroBioTech Transfer Center. 
Table 2: Thematic priorities of Horizon 2020 relevant for agri-food sector

\begin{tabular}{|l|l|}
\hline Food and bioeconomy & $\begin{array}{l}\text { sustainable agriculture, sustainable and competitive agri-food sector for a safe and healthy food, water } \\
\text { resources, bioeconomy }\end{array}$ \\
\hline Health & nutrition for health \\
\hline Energetics & agriculture and alternative energy resources \\
\hline Climate & $\begin{array}{l}\text { eco-innovations, waste management, use of natural resources, the impact of agriculture and food } \\
\text { industry on climate change, protection of water recources }\end{array}$ \\
\hline Biotechnology & use of biotechnology in agriculture and food industry, including industrial processes and products \\
\hline ICT & use of information and communication technologies in agriculture and food industry \\
\hline Innovation in SMEs & $\begin{array}{l}\text { cross-sectional themes of innovation (clusters, new methods of funding and support, open and social } \\
\text { innovations) }\end{array}$ \\
\hline
\end{tabular}

Source: Innovative financial instruments and financing the research, development and innovations for practice. The report was prepared within the project Creation of the AgroBioTech Research Centre, Activity 1.7: AgroBioTech Transfer Center.

environment and climate action (LIFE), EU program for education, training, youth and sport (Erasmus+).

- European territorial cooperation (Interreg): Transnational cooperation Interregional cooperation, Cross-border cooperation.

- Partnerships and initiatives for research and innovation: European Technology Platforms (ETPs), Joint European Initiatives (JTIs), European Institute of Innovation and Technology (EIT), European Innovation Partnerships (EIP).

- Financial instruments for supporting the research and innovation of the European Investment Fund (EIF) and the European Investment Bank (EIB).

Overview of possibilities within the area of community funds and initiatives is displayed in table 1.

Since the 80s' of the previous century, the European Union has been coordinating research activities through the so-called framework programs (FPs). In the current period 2014-2020, already the eighth FP, titled Horizon 2020, has been implemented. With a budget of about 80 billion EUR, it belongs to the largest EU programs. For the first time, such program connects the whole innovation cycle from the basic and applied research, through testing and demonstration activities, to the preparation of new products and their placement on the market. Table 2 briefly describes the basic areas of thematic priorities that are relevant for the agri-food sector.

The specific objective of specific priority - Innovation in small and medium-sized enterprises (SMEs) ${ }^{(18)}$ is to encourage sustainable economic growth of SMEs by increasing the level of innovation, and by covering their innovation needs throughout the innovation cycle of all types of innovation and, therefore, to create a faster-growing, internationally active SMEs. The aim of the proposed actions is to amend

(18) Definition of SME: The category of micro, small and mediumsized enterprises (SMEs) is made up of enterprises which employ fewer than 250 persons and which have an annual turnover not exceeding 50 million EUR, and/or an annual balance sheet total not exceeding 43 million EUR. These upper limits apply to individual company data. It is possible that a company that is part of a larger group would have to include the employees, turnover or assets of other companies in the group. On the basis of the Commission Recommendation 2003/361/ EC. national and regional policies and programs in the field of business innovation; to enhance cooperation between SMEs, including transnational cooperation, clusters and other subjects in Europe that are essential for innovation; to bridge the gap between R\&D and successful market launch; to create an environment that is more favorable for business innovation, including demand-side measures and measures aimed at promoting knowledge transfer; and to provide support taking into account the changing nature of innovation processes, new technologies, markets and business models.

To support the launch of new products and services on the market, the European Commission introduced a new type of project, called the SME Instrument, which is built on the successful American scheme SBIR (Small Business Innovation Research). SME instrument is targeted at all types of innovative SMEs showing a strong ambition to develop, grow and internationalize. It is provided for all types of innovation, including non-technological and social innovation, on the condition that each activity has a clear European added value. The main aim is to overcome the lack of funding for the initial stages of high-risk research and innovation, stimulate break-through innovations and increase the commercialization of research results in the private sector. All of the specific objectives of the priority Societal challenges, and of the specific objective Leadership in enabling and industrial technologies use the tool instrument specified for SMEs and will contribute to it with an appropriate amount. By doing so, the minimum target - which is to provide SMEs with $20 \%$ of the total combined budgets will be achieved.

New scheme for supporting the rapid implementation of innovations in Horizon 2020 is the Fast Track to Innovation (FTI) that supports innovation projects designed by users in accordance with the $2^{\text {nd }}$ and $3^{\text {rd }}$ pillar of Horizon 2020 (Industrial Technology and Societal Challenges). FTI funds projects close to the market (with completed R\&D that are not yet commercially deployed), which will be implemented by small international consortia. The purpose of this scheme is to support projects that would not get funding from commercial sources otherwise, and to reduce the time of launching new solutions to the market. FTI scheme does not limit the participation of the corporate sector only to SMEs and therefore, large companies are able to participate. FTI scheme supports following two types of projects: 
- Development of product/service initiated by the business sector, where the idea usually comes from the company that leads the consortium and intends to cooperate with international partners on product development (other companies, universities, research organizations).

- Spin-out from the public sector, where the idea comes from a research organization or university that will create business for developing the product and equip it with the relevant intellectual property rights. This public research organization is usually the leader of the consortium and intends to cooperate with other international partners on the product development.

Project FTI may therefore include the following activities: validation systems under real operating conditions, testing, pilots, validation of the business models, setting the standards, pre-normative research, ensuring brand quality EU.

In Horizon 2020, term International cooperation refers to cooperation with non-EU countries. Unlike previous framework programs of the EU, Horizon 2020 integrates international cooperation into the general rules valid for all projects. The new strategy of cooperation defined by the EU in 2012, focuses on the intense connection of the European Research Area and research and innovation potential of non-EU countries. To achieve these objectives in the areas of mutual interest and to achieve benefits, cooperation with three groups of countries is supported:

- industrialized countries (receive funding only under specific conditions);

- accessible and neighboring countries (eligible for automatic funding);

- Developing countries (eligible for auto funding).

Approximately 5\% countries outside the EU participated in the previous Framework Program (FP7). The main representatives were BRICS countries (Brazil, Russia, India, China and South Africa), Ukraine and the USA. Every fifth project had a partner from non-EU country. Non-EU countries or "third countries" are generally understood as countries or territories, which are not part of the EU-28 or overseas territories and territories linked to the EU countries.

European Territorial Cooperation (ETC) also known as the Interreg is one of the two objectives of the EU cohesion policy and provides a platform for the implementation of joint activities and exchange of experience in various policies between national, regional, and local actors from different Member States. The main objective of the ETC is to promote balanced economic, social, and territorial development of the EU as a whole. Currently, the Interreg is key instrument to support cooperation between the partners beyond the boundaries of individual states. Within the ETC for the programming period 2014-2020 (referred to as Interreg A) from the European Regional Development Fund (ERDF) following cooperations are supported: cross-border (Interreg A), transnational (Interreg B) and interregional (Interreg C). For individual forms of cooperation in the 2014-2020 period, EU allocated funds in amount of 10.1 billion EUR, while Interreg $\mathrm{V}$ focuses on 11 investment priorities contributing to the achieving the aims of the Europe 2020 strategy, includ- ing the research and innovation.

Transnational cooperation is realized within larger transnational territories, while including national, regional and local authorities. It covers large areas of cooperation, such as Central Europe, the Danube region, the Baltic area, Alpine region, etc. Overall, it is about 15 cooperation programs with a budget of 2.1 billion EUR. Danube Program (Interreg Danube Transnational Program) is one of three transnational cooperation programs that follow up on South East Europe program in the new programming period. New Danube program supports cooperation in the countries of the Danube region in order to support the implementation and management of the Danube Strategy. Countries participating in the program are Germany (Baden-Württemberg and Bavaria), Austria, Slovakia, the Czech Republic, Hungary, Slovenia, Romania, Bulgaria, Croatia, Serbia, Bosnia and Herzegovina, Montenegro, Moldova and Ukraine. Ministry of National Economy of Hungary performs the function of the managing authority. The program is financially supported from the ERDF, with a budget of about 211 million EUR. Costs of Slovak project partners can be supported from the ERDF up to $85 \%$. The minimum requirement for the project in terms of partnership, is a cooperation of 3 partners from at least three countries, while the project always includes the project coordinator and the other project partners. Other conditions regarding partners are regulated within specific calls for proposals.

Interregional cooperation - INTERREG VC is aimed at strengthening the effectiveness of the EU cohesion policy by supporting the exchange of experience among the partners in the whole EU (INTERREG EUROPE), including three programs of networking (Urbact III, Interact III and ESPON), with emphasis on the identification, dissemination and transfer of examples of best practice not only between ETC programs, but also to programs under the objective "Investment for growth and jobs". For its implementation, ERDF allocated funds amounting to 500 million EUR.

In 2014-2020, Eurostars is already the second generation of R\&D program carried out jointly with several Member States that is aimed at supporting of SMEs performing $\mathrm{R} \& \mathrm{D}$. It focuses on business-oriented projects in research, development and innovations, which can contribute to the growth of Europe's competitiveness. Mainly projects that have a significant positive impact on the development of new technology, innovation, market and competitive conditions of participating SMEs are supported. Funding of projects for all types of organizations (SMEs, large companies, universities, academic and non-profit organizations) creates 50\% of eligible costs, but no more than 150000 EUR. Currently, the program involves 33 member countries of EUREKA ${ }^{(19)}$ initiative. Eurostars aims particulartly at support of SMEs with intensive R\&D and with high growth potential. Project application is submitted by an international consortium, whose main applicant (i.e. coordinator of an international consor-

(19) Belgium, Bulgaria, Cyprus, the Czech Republic, Denmark, Estonia, Finland, France, Greece, Croatia, Iceland, Ireland, Israel, Latvia, Lithuania, Luxembourg, Hungary, Malta, Germany, Norway, Poland, Portugal, Romania, Slovakia, Slovenia, United Kingdom, Spain, Switzerland, Sweden, Italy and Turkey. 
tium) is the SME with intensive R\&D in one of the Member States of the Eurostars Program.

SMEs are the pillar of the European economy and create $85 \%$ of all new work positions. The European Commission aims to support entrepreneurship and improve the business environment for SMEs, so they are able to achieve its full potential in the current globalized economy. COSME is the EU program for the competitiveness of enterprises and SMEs for the period 2014-2020, with a budget of 2.3 billion EUR. The COSME program supports SMEs in the following areas(20): improving the access to financing, support for internationalization and access to markets, creation of an environment supporting competitiveness and encouraging of an entrepreneurial culture.

European Technology Platforms (ETPs) are forums of relevant actors conducted by industry and recognized by the European Commission as key actors in the management of innovation, knowledge transfer and European competitiveness. ETPs propose research and innovation programs, as well as, plans for the implementation of measures at EU and national level that are supported by private and public finance. Stakeholders are mobilized in support of agreed priorities and sharing information across the EU. Effective cooperation also helps in providing solutions to important issues of crucial importance to citizens, such as the aging society, environmental protection, food and energy security. ETPs are independent entities with their own funding that carry out their activities transparently and are open to new members. EC approved and currently registers technology platforms in the following areas : bio-economy, energy, environment, ICT, production processes, transport and crosssectoral initiatives.

European Innovation Partnerships (EIP) are new concept for research and innovations, presented in the Innovation in the Union and the Europe 2020 strategy. Partnerships are aimed at specific societal challenges. They are focused on results, outcomes and impacts, they remove barriers to the innovation process and have clear added value. EIPs bring together stakeholders from the private and public sector across sectors and boundaries in order to speed up the process of innovation implementation through new concept of solution of the chain research - development - innovation. EIPs are not financial instrument, however, they reengineer, simplify and coordinate existing instruments and initiatives, and complement them with new steps in the areas where it is needed. EIPs exist only in areas where a combination of EU, national and regional efforts in R\&D and on the demand side is achieving target faster and more efficiently.

One of the five EIPs is the EIP-AGRI Agricultural productivity and sustainability. This partnership responds to the issues of food security and ensurance of productivity. Its purpose is to secure functional link between agriculture, bio-economy, science and other actors at the EU, national and regional levels. EIP-AGRI was launched by the European Commission in 2012 and the main slogan of this partnership is "to achieve more from less". The partnership set out two

(20) The list of all current ETPs is available on the website: http:// ec . europa.eu/research/innovation-union/index en. c fm?pg=etp main objectives: to promote the productivity and efficiency of the agricultural sector (to reverse the recent downward trend in productivity till 2020); agricultural sustainability (to ensure a satisfactory level of land functionality till 2020). EIP-AGRI network brings together a variety of stakeholders as partners in various types of innovative actions such as working groups and projects of several actors. Farmers, consultants, researchers, agricultural industry, NGOs and other actors in agriculture and forestry work together to share their ideas and knowledge in order to create innovative solutions. EIP-AGRI network is managed by the European Commission (DG AGRI) by EIP-AGRI service centers.

\section{Conclusion}

The authors of the paper described selected legal and financial mechanisms for implementation of innovations. Their implementation in economic practice, especially in the agri-food sector is often complicated and accompanied by number of problems. The implementation of innovations is necessary for the agri-food sector, its economic growth, competitiveness and sustainability. Innovations often interfere in the activities of enterprises despite the fact that businesses do not even realize it. In many cases, innovations are implemented after the problem occurs, and so they become solution to the problem.

The current state of the agri-food sector calls for implementation of changes, and requires to change outdated systems and structures to newer, more modern, more powerful, more flexible. This may be considered as the basis for business success. Innovations are the driving force of socioeconomic development; therefore, it is essential to recognize their need and importance in all sectors of the economy, as well as, to operationalize the existing legislative environment and support mechanisms.

\section{References}

1. BALOG, M. et al. (2013). Inovatívne Slovensko - východiská a výzvy. Slovenská inovačná a energetická agentúra, Bratislava, 2013.

2. ČOREJ, J. et al. (2006). Univerzity, priemysel a partnerstvo. Žilinská univerzita v Žiline: EDIS 2006, ISBN 80-8070-526-7.

3. ETZKOWITZ, H. - WEBSTER, A. - GEBHARDT, C. - TERRA, B. R. C. (2000). The Future of the University and the University of the Future: Evolution of Ivory Tower to Entrepreneurial Paradigm. Research Policy, vol. 29, no. 2, pp. 313 - 330. Online. [Cit. 2016-09-11.] Available through access to electronic sources of information of CVTI SR

4. EUROPEAN COMMISSION. (2010). Communication Europe 2020 Flagship Initiative Innovation Union COM (2010) 546 final, 6.10.2010.

5. EUROPEAN COMMISSION. (2014). The role of public support in the commercialisation of innovations (Flash Eurobarometer 394). Available at: 〈http://ec.europa.eu/public_opinion/ flash/fl_394_en.pdf>

6. FORTUIN, F. (2007). Strategic alignment of innovation to business. Balancing exploration and exploitation in short and long life cycle industries. Wageningen: Wageningen Academic Publishers.

7. GEUNA, A. - MUSCIO, A. (2009). The Governance of Univer- 
sity Knowledge Transfer: A Critical Review of the Literature. Journal of Technology Transfer, vol. 47, no. 1, pp. 93 - 114. Online. [Cit. 2016-09-11]. Available through access to electronic sources of information of CVTI SR.

8. HAMEL, G. - PRAHALAD, C.K. (1994). Competing for the Future. Boston: Harvard Business School Press, 1994.

9. INTER-AMERICAN INSTITUTE FOR COOPERATION ON AGRICULTURE. (2014). Innovation in Agriculture: a key process for sustainable development. Institutional position paper, San Jose, May 2014

10. IZSAK, K. - EDLER, J. (2011). Trends and Challenges in Demand-Side Innovation Policies in Europe. Thematic Report 2011 under Specific Contract for the Integration of INNO Policy TrendChart with ERAWATCH (2011 - 2012). Brusel: European Commission, DG Industry and Enterprise. Online. [Cit. 201609-11]. Available at: http://ec.europa.eu/enterprise/ newsroom/cf/_getdocument. c fm?doc_id=7011.

11. JAKL, L. et al. (2016). Aktuální otázky práv k duševnímu vlastnictví. Praha: Metropolitan University Praque Press. 2016. 314 p. ISBN 978-80-87956-32-8.

12. KLERKX, L. - GILDEMACHER, P. (2012). The Role of Innovation Brokers in Agricultural Innovation Systems. Agricultural Innovation Systems: An Investment Sourcebook. Online. [Cit. 2016-09-11]. Available at: http: //www-wds. wor ldbank .org/ external/default/WDSContentServer/WDSP/IB/2012/03/0 1/000356161_20120301005432/Rendered/PDF /672070PUB0E PI0067844B09780821386842.pdf

13. KNICKEL at al. (2009). Innovation processes in agriculture and rural development. Online. [Cit. 2016-09-11]. Available at: http: //www . insightproject.net/files/IN-SIGHT_final_ report.pdf.

14. LEYERSDORFF, L. - MEYER, M. (2009). The Decline of University Patenting and the End of the Bayh-Dole Effect. Scientometrics, vol. 83, no. 2, pp. 355-362. Online. [Cit. 2016-29-10.] Available through access to electronic sources of information of CVTI SR.

15. TELC, I. - TUMA, P. (2006). Přehled práva duševního vlastníctva. Česká právní ochrana 2. Brno: Nakladateství Doplněk, 2006. 14p. ISBN 80-7239-198-4

16. VOJČÍK, P. et al. (2012). Právo duševného vlastníctva Plzeň: Vydavatelství a nakládatelství Aleš Čeněk, s.r.o., 2012. 495 p. ISBN 978-80-7380-373-5.

\section{Contact address/ Kontaktná adresa}

doc. Mgr. Ing. Danka Moravčíková, PhD.

Department of Social Sciences, FEM, SUA in Nitra,

Tr. A. Hlinku 2, 949 76, Nitra,

e-mail: danka.moravcikova@uniag.sk

doc. JUDr. Zuzana Ilková, PhD.

Department of Law, FESRD, SUA in Nitra,

Tr. A. Hlinku 2, 949 76, Nitra,

e-mail: zuzana.ilkova@uniag.sk

JUDr. Ing. Petra Štefeková, PhD.

student, FEM, SUA in Nitra,

Tr. A. Hlinku 2, 949 76, Nitra,

e-mail: xstefekovap@is.uniag.sk 